\title{
Alkaloids and Flavone Acyl Glycosides from Acanthus arboreus
}

\author{
Masouda E. Amer ${ }^{a}$, Mohamed I. Abou-Shoer ${ }^{a}$,Maged S. Abdel-Kader ${ }^{*, a}$, Amina M.S. El-Shaibany ${ }^{b}$ \\ and Nabil A. Abdel-Salam ${ }^{a}$ \\ ${ }^{a}$ Department of Pharmacognosy, Faculty of Pharmacy, Alexandria University, Alexandria, Egypt \\ ${ }^{b}$ Department of Pharmacognosy, Faculty of Medicine, Sana'a University, Sana'a, Yemen
}

O estudo fitoquímico de Acanthus arboreus resultou no isolamento de 3 novos alcalóides: 6hidróxi-2-benzoxazolinona, 4-hidróxi-acantamina (3,4-di-hidróxi-1,4-benzoxazino-2-ona) e acantaminosídeo (3-O-glicopiranosídeo-1,4-benzoxazino-2-ona). Além destes alcalóides foi também isolado o novo flavonóide 7-O- $\beta$-D(6"-trans-p-cumaroil)3"-O-acetilglicopiranosídeo apigenina e os seguintes compostos de estruturas já conhecidas: apigenina, 7-O- $\beta$-D(6"-trans-p-cumaroil)3"-Oglicopiranosídeo apigenina, ácido vanílico, lupeol, estigmasterol e 3- $\beta$-glicopiranosídeo sitosterol. As estruturas dos compostos foram determinadas por métodos espectroscópicos e transformações químicas.

Phytochemical study of Acanthus arboreus resulted in the isolation of three novel alkaloids: 6hydroxy-benzoxazolinone, 4-hydroxyacanthamine and acanthaminoside. In addition, a new acyl flavonoid apigenin-7- $O$ - $\beta$-D-(6"-trans- $p$-coumaroyl)-3"- $O$-acetyl glucopyranoside was also isolated. The known compounds were identified as apigenin, apigenin-7- $O-\beta$-D-(6"-trans- $p$-coumaroyl)glucoside, vanillic acid, lupeol, stigmasterol and sitosterol glucoside. The structures were determined by physical, chemical and spectral techniques. activity

Keywords: Acanthus arboreus, Acanthaceae, alkaloids, flavone acyl glycosides, antimicrobial

\section{Introduction}

The Acanthaceae is a large family with more than 250 genera and 2700 species. ${ }^{1}$ Chemical investigation of genus Acanthus resulted in the isolation of flavonoids, alkaloids, triterpenoids and sterols. ${ }^{2-5}$ A. ilicifolius is used as anticonvulsant, hypnotic and skeletal muscle relaxant due to the presence of benzoxazolinone; an alkaloid with CNS depressant activity. ${ }^{6,7}$

Benzoxazolinone also exhibited antiprotozoal activity against Leishmania donovani in vitro; while its ribose derivatives were active as anticancer and antiviral agents. ${ }^{5,8}$

\section{Results and Discussion}

The HRCI-MS of 1 showed an $\mathrm{M}^{+}+1$ at $m / z, 579.151$ for the molecular formula $\mathrm{C}_{30} \mathrm{H}_{26} \mathrm{O}_{12}$. Physical and spectral data of 1 were identical with those reported for apigenin $O-\beta$ D-(6"-trans-p-coumaroyl)-glucoside isolated from Pogostemon cablin. ${ }^{9}$ However, Singh et al in 1986 reported the same compound as a novel product from Echinops

\footnotetext{
* e-mail: mpharm101@ @otmail.com
}

echinatus under the name echinacin. ${ }^{10}$ Based on COSY and HMQC experiments, complete assignments for the sugar protons and all carbons were achieved. Our assignments were in complete agreement with first publication. ${ }^{9}$ However, some of the ${ }^{13} \mathrm{C}$-NMR assignments in the latter publication ${ }^{10}$ must be revised.

The HRCI-MS $\left(\mathrm{M}^{+}+1\right.$ at $m / z, 621.161$ for the molecular formula $\mathrm{C}_{32} \mathrm{H}_{28} \mathrm{O}_{13}$ ) and other spectral data of 4 (see experimental) indicated an additional acetyl group compared with 1. Complete assignments of the sugar protons could be achieved by a combination of COSY and HMQC experiments. A major difference was observed in the chemical shift of $\mathrm{H}-3^{\prime \prime}(\delta 4.97, \mathrm{t})$ compared to that of $\mathbf{1}(\delta 3.30, \mathrm{~m})$, indicating that the acetyl group is located at C-3". Further evidence for the position of the acetyl group was obtained from the ${ }^{13} \mathrm{C}$ NMR, where a substantial downfield shift $\Delta_{\delta \mathrm{C}-3,}=1.20 \mathrm{ppm}$ and the upfield shift of C-2" and C-4" $\left(\Delta_{\delta \mathrm{C}-2},=1.66 \mathrm{ppm}\right.$ and $\left(\Delta_{\delta \mathrm{C}-4},=1.67 \mathrm{ppm}\right)$ relative to those of 1 were observed. ${ }^{11} \mathrm{~A}$ literature search revealed that 4 (apigenin $7-O-\beta-\mathrm{D}\left(6^{\prime \prime}\right.$-trans$p$-coumaroyl) 3 "-O-acetylglucopyranoside) is a previously unreported natural compound.

The new alkaloid 2 gave positive reactions with $\mathrm{FeCl}_{3}$, Lassaigne and ninhydrin reagents indicating its phenolic 
nitrogenous nature. HREI-MS (experimental) showed an $\mathrm{M}^{+}$at $m / z, 151.027$ for the molecular formula $\mathrm{C}_{7} \mathrm{H}_{5} \mathrm{O}_{3} \mathrm{~N}$. It also showed characteristic mass fragments at $\mathrm{m} / \mathrm{z}$ 105, 95, 91 and 77, suggesting the presence of 2-benzoxazolinone. ${ }^{12}$ In the ${ }^{13} \mathrm{C}-\mathrm{NMR}$ spectrum (Table 1 ) the seven carbons were resolved as three aromatic methines $(\delta 99.1,111.0$ and 111.6) assigned to C-7, C-5 and C-4 respectively, three quanternary aromatic carbons $(\delta 129.9,146.1$ and 154.8) attributed to C-9, C-8 and C-6 respectively, and a fourth quaternary carbon at $\delta 157.7$ assigned to the lactone carbonyl. The ${ }^{1} \mathrm{H}-\mathrm{NMR}$ spectrum (Table 1) showed an ABX system at $\delta 6.68(1 \mathrm{H}, \mathrm{d}, J 2.3 \mathrm{~Hz}), 6.85(1 \mathrm{H}, \mathrm{d}, J 8.5 \mathrm{~Hz})$ and $6.60(1 \mathrm{H}, \mathrm{dd}, J 2.3,8.5 \mathrm{~Hz})$ indicating a trisubstituted aromatic system. Compound $\mathbf{2}$ was identified as the demethyl derivative of 6-methoxy-benzoxazolinone i.e. 6-hydroxy-benzoxazolinone. Even the known 6-methoxybenzoxazolinone is a rare natural product isolated only once from Corn plants. ${ }^{13}$

Chemical reactions and solubility in $\mathrm{NaOH}$, followed by recovery after acidification, suggested that $\mathbf{3}$ is a nitrogenous compound with a lactone function. This was confirmed by the IR absorption bands for carbonyl $\left(1670 \mathrm{~cm}^{-1}\right)$, hydroxy and/or NH groups $\left(3325 \mathrm{~cm}^{-1}\right)$. The HRCI-MS showed an $\mathbf{M}^{+}+1$ at $m / z, 182$, and an $\mathbf{M}^{+}$at $m / z$ 181.144 for the molecular formula $\mathrm{C}_{8} \mathrm{H}_{7} \mathrm{O}_{4} \mathrm{~N}$. The ${ }^{13} \mathrm{C}-\mathrm{NMR}$ spectrum (Table 1) showed five methine signals and three quaternary carbons. In the ${ }^{1} \mathrm{H}-\mathrm{NMR}$ spectrum the coupling pattern of the 4 aromatic protons suggested the presence of an $O$-disubstituted benzene ring. In the ${ }^{1} \mathrm{H}-\mathrm{NMR}$ spectrum the singlet at $\delta 5.68$, diagnostic for a proton flanked by two electronegative atoms, was assigned for $\mathrm{H}-3$. This was supported by a ${ }^{13} \mathrm{C}-\mathrm{NMR}$ signal which appeared at $\delta 93.7$ and was attributed to the oxymethine carbon. The remaining three quaternary carbon absorptions at $\delta 129.7,142.5$ and 160.1 were assigned to C-10, C-9 and the carbonyl group respectively. The violet colour with $\mathrm{FeCl}_{3}{ }^{14}$ as well as the $\mathrm{M}^{+}$of the diacetate derivative 3a at $\mathrm{m} / \mathrm{z} 265$ indicated the presence of a hydroxylamine group. The exact positions of the carbonyl and hydroxyl groups were established from alkaline hydrolysis and by the inability of $\mathbf{3}$ to give $O$-aminophenol after fusion with $\mathrm{KOH}$. This clearly distinct the new alkaloid 3 (3,4-dihydroxy-1,4-benzoxazine-2-one) from blepharigenin (2-hydroxy-1,4-benzoxazine-3-one) a compound with very close ${ }^{1} \mathrm{H}-\mathrm{NMR}$ data. ${ }^{15}$

The HRCI-MS of the third new alkaloid $\mathbf{5}$ showed $\mathrm{M}^{+}$ at $m / z, 327.095$ for the molecular formula $\mathrm{C}_{14} \mathrm{H}_{17} \mathrm{O}_{8} \mathrm{~N}$. The

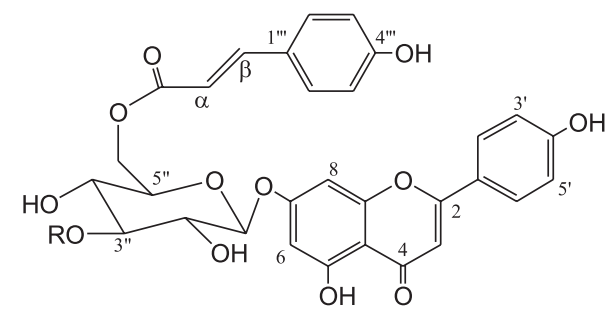

1: $\mathrm{R}=\mathrm{H}$

4: $\mathrm{R}=\mathrm{COCH}_{3}$

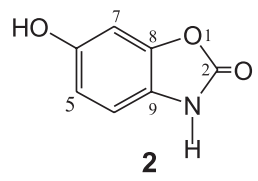

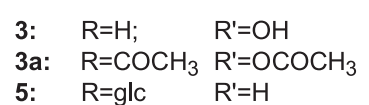

Table 1. ${ }^{1} \mathrm{H}$ - and ${ }^{13} \mathrm{C}-\mathrm{NMR}$ spectral data of compounds $\mathbf{2}, \mathbf{3}$ and $\mathbf{5}$ (coupling constants in $\left.\mathrm{Hz}\right)^{\mathrm{a}}$

\begin{tabular}{|c|c|c|c|c|c|c|}
\hline \multirow[b]{2}{*}{$\#$} & \multicolumn{2}{|c|}{$2^{\mathrm{b}}$} & \multicolumn{2}{|c|}{$\mathbf{3}^{\mathrm{b}}$} & \multicolumn{2}{|c|}{$5^{\mathrm{c}}$} \\
\hline & ${ }^{1} \mathrm{H}$ & ${ }^{13} \mathrm{C}$ & ${ }^{1} \mathrm{H}$ & ${ }^{13} \mathrm{C}$ & ${ }^{1} \mathrm{H}$ & ${ }^{13} \mathrm{C}$ \\
\hline 2 & - & 157.7 & & 160.1 & - & 162.6 \\
\hline 3 & - & - & $5.68 \mathrm{~s}$ & 93.7 & $5.78 \mathrm{~s}$ & 96.4 \\
\hline 4 & $6.85 \mathrm{~d} J 8.5$ & 111.6 & - & - & - & - \\
\hline 5 & $6.60 \mathrm{dd}, J 2.3,8.5$ & 111.0 & $7.36 \mathrm{dd} J 1.6,7.8$ & 114.4 & $7.12 \mathrm{~m}$ & 119.1 \\
\hline 6 & - & 154.8 & $7.08 \mathrm{~m}$ & 125.6 & $7.05 \mathrm{~m}$ & 124.9 \\
\hline 7 & $6.68 \mathrm{~d} J 2.3$ & 99.1 & $7.08 \mathrm{~m}$ & 123.8 & $7.05 \mathrm{~m}$ & 124.2 \\
\hline 8 & - & 146.1 & $7.01 \mathrm{dd} J 1.6,7.8$ & 118.5 & $6.99 \mathrm{~m}$ & 116.9 \\
\hline 9 & - & 129.9 & & 142.5 & & 142.0 \\
\hline 10 & & & & 129.7 & & 127.4 \\
\hline 1 ' & & & & & $4.70 \mathrm{~d} J 7.8$ & 104.0 \\
\hline $2^{6}$ & & & & & $3.28 \mathrm{~m}$ & 74.9 \\
\hline $3^{6}$ & & & & & $3.30-3.34 \mathrm{~m}$ & 78.0 \\
\hline $4^{6}$ & & & & & $3.30-3.34 \mathrm{~m}$ & 71.1 \\
\hline $5^{\prime}$ & & & & & $3.30-3.34 \mathrm{~m}$ & 78.6 \\
\hline $6^{6}$ & & & & & $3.83 \mathrm{~d} J 11.9$ & 62.5 \\
\hline & & & & & $3.68 \mathrm{dd} J 3.6,11.9$ & \\
\hline
\end{tabular}

a Assignments are based on HMQC experiments; ${ }^{b}$ Spectra were measured in $\mathrm{CD}_{3} \mathrm{OD}$; ${ }^{\mathrm{c}}$ Spectra were measured in $\mathrm{CD}_{3} \mathrm{OD} / \mathrm{DMSO}$ mixture 
14 carbon signals were clear in the ${ }^{13} \mathrm{C}$-NMR spectrum (Table 1), of which 8 signals were accounted for the aglycone part, while the remaining 6 carbon signals were assigned for the sugar moiety. The 1,4-benzoxazine-2-one skeleton was assigned to 5 rather than the 1,4-benzoxazine3 -one as indicated from its reaction with $\mathrm{KOH}$ solution and fusion test. ${ }^{15}$ The spectral data of $\mathbf{5}$ aglycone (Table 1 and Experimental) showed a close similarity to $\mathbf{3}$. However, the CI-MS and the negative reaction with $\mathrm{FeCl}_{3}$ suggested the absence of a hydroxyl group attached to nitrogen atom. Consequently, the only possible site for glycosylation is the C-3 hydroxyl. The identity of the sugar moiety was established as glucose by spectral evidences and by TLC comparison after acid hydrolysis. On the basis of the chemical shift and coupling constant of the anomeric proton $\left(J_{1 ‘, 2} 7.8 \mathrm{~Hz}\right)$, the glucosidic linkage should have the $\beta$-orientation. The identity of $\mathbf{5}$ was therefore established as 1,4-benzoxazine-2-one-3-O-glucoside.

The known compounds were identified by direct comparison with reference materials (Aldrich).

Compounds $\mathbf{1}$ and 3-5 were subjected to antimicrobial testing using 10 microorganisms. Only compounds $\mathbf{1}$ and 4 were active against Bacillus subtilis with an MIC 64 and $128 \mu \mathrm{g} / \mathrm{mL}$ respectively.

\section{Experimental}

\section{General procedure}

The CI-MS of 3a was measured on a Finnigan SSQ7000 mass spectrometer. NMR spectra were recorded on a JEOL $500 \mathrm{NMR}$ instrument at $500 \mathrm{MHz}$ for ${ }^{1} \mathrm{H}$ and $125 \mathrm{MHz}$ for ${ }^{13} \mathrm{C}$. Other experimental conditions were as previously described. ${ }^{16}$

\section{Plant material}

The whole plants of Acanthus arboreus Forssk. growing wild in Wadi Dhar, Sana'a, Yemen was collected during the flowering stage in August 1998 and was identified by Prof. Nabil El-Hadidy, Department of Plant Taxonomy, Faculty of Science, Cairo University. A voucher sample (YA1) is preserved in the Department of Pharmacognosy, Faculty of Pharmacy, University of Alexandria, Egypt.

\section{Extraction and isolation}

The air-dried powdered whole plant of Acanthus arboreus Forssk (3.5 kg) were extracted by $95 \%$ ethanol at room temperature. The concentrated ethanolic extract was partitioned between $\mathrm{CHCl}_{3}(1 \mathrm{~L})$ and water $(1 \mathrm{~L})$. The $\mathrm{CHCl}_{3}$ fraction $(80 \mathrm{~g}$ ) was again partitioned between $90 \% \mathrm{MeOH}$ (1L) and petroleum ether (1L). The aqueous fraction was extracted with EtOAc $(3 \times 500 \mathrm{~mL})$, then with $n$-butanol (3x500 mL).

A sample (10 g) of the $90 \%$ methanolic extract (26 g) was chromatographed on silica gel column $(200 \mathrm{~g}, 4 \mathrm{~cm})$ eluted with petroleum ether- $\left.\mathrm{CH}_{2} \mathrm{Cl}_{2}\right)(1: 1)$ with increasing content of $\mathrm{CH}_{2} \mathrm{Cl}_{2}$, then methanol. Fractions of $250 \mathrm{ml}$ each were collected, screened by TLC and similar fractions were combined. Fractions 6-15 (1.9 g, petroleum ether/ $\left.\mathrm{CH}_{2} \mathrm{Cl}_{2} 40: 60\right)$ afforded lupeol (800 mg) upon crystallization from petroleum ether. Crystallization of fractions 16-20 (0.8 g, petroleum ether/ $\left.\mathrm{CH}_{2} \mathrm{Cl}_{2} 25: 75\right)$ from methanol gave stigmasterol (100 mg). Fractions 36-42 (0.9 g, $\mathrm{CH}_{2} \mathrm{Cl}_{2} /$ $\mathrm{MeOH}$ 92.5:7.5) were rechromatographed on silica gel column $(30 \mathrm{~g}, 1 \mathrm{~cm})$ eluted with a mixture of EtOAc/MeOH with increasing proportion of $\mathrm{MeOH}$. Fractions of $50 \mathrm{ml}$ each were collected. Fractions 5-10 were further purified by PTLC on silica gel plates developed with $\mathrm{CHCl}_{3} / \mathrm{MeOH}$ (9:1)(double development) and the zone with an $\mathrm{R}_{f}$ value of 0.54 was scraped off, eluted with a mixture of chloroform and methanol (1:1) to afford $\mathbf{1}(160 \mathrm{mg})$. Fractions 43-47 (1.1 g, $\mathrm{CH}_{2} \mathrm{Cl}_{2} / \mathrm{MeOH}$ 90:10) gave sitosterol glucoside $(230 \mathrm{mg}$ ) on crystallization from methanol.

The EtOAc extract (12 g) was fractionated on silica gel column (400 g, $3 \mathrm{~cm}$ ) eluted with $\mathrm{CH}_{2} \mathrm{Cl}_{2}$ and $\mathrm{CH}_{2} \mathrm{Cl}_{2}$ / $\mathrm{MeOH}$ mixtures with gradual increase of methanol content. Ninety fractions (150 mL each) were collected. Repeated crystallization of fraction $12\left(0.85 \mathrm{~g}, \mathrm{CH}_{2} \mathrm{Cl}_{2} / \mathrm{MeOH} 98: 2\right)$ from methanol afforded vanillic acid (200 $\mathrm{mg}$ ). Crystallization of fractions 25-29 (0.78 g, $\mathrm{CH}_{2} \mathrm{Cl}_{2} / \mathrm{MeOH}$ 97:3) from methanol afforded apigenin (10 mg); while PTLC of the supernatant on silica gel plates developed with $\mathrm{CHCl}_{3} / \mathrm{MeOH}(8: 2)$ gave $5 \mathrm{mg}$ of $2\left(\mathrm{R}_{f}=0.58\right)$. Fractions 36-45 (2.1 g, $\left.\mathrm{CH}_{2} \mathrm{Cl}_{2} / \mathrm{MeOH} 96: 4\right)$ were crystallized from methanol to give $3(850 \mathrm{mg})\left(\mathrm{R}_{f}=0.34\right.$ EtOAc/MeOH/ $\left.\mathrm{H}_{2} \mathrm{O} 30: 5: 2\right)$. Crystallization of fractions 4955 (1.6 g, $\left.\mathrm{CH}_{2} \mathrm{Cl}_{2} / \mathrm{MeOH} 94: 6\right)$ from methanol gave 4 $(620 \mathrm{mg})\left(\mathrm{R}_{f}=0.30 \mathrm{EtOAc} / \mathrm{MeOH} / \mathrm{H}_{2} \mathrm{O} 30: 5: 2\right)$. Additional quantity of $\mathbf{1}$ (210 mg) was obtained by crystallization of fractions 78- 81(1.4 g, $\left.\mathrm{CH}_{2} \mathrm{Cl}_{2} / \mathrm{MeOH} 90: 10\right)$ from $\mathrm{MeOH}$.

A sample $(8 \mathrm{~g})$ of the $n$-butanol extract $(30 \mathrm{~g})$ was chromatographed of a silica gel column (160 g, $2 \mathrm{~cm})$ eluted with $\mathrm{CH}_{2} \mathrm{Cl}_{2}$ and $\mathrm{CH}_{2} \mathrm{Cl}_{2} / \mathrm{MeOH}$ mixtures with a gradual increase of methanol content. Twenty five fractions (100 mL each) were collected. Fractions 13-16 (0.7 g, $\mathrm{CH}_{2} \mathrm{Cl}_{2} / \mathrm{MeOH}$ 80:20) afforded 5 (120 mg) $\left(\mathrm{R}_{f}=0.47\right.$ EtOAc/MeOH/ $\left.\mathrm{H}_{2} \mathrm{O} 30: 5: 4\right)$ on crystallization from $\mathrm{MeOH}$.

Apigenin 7-O- $\beta$-D-(6"-trans-p-coumaroyl) glucoside (1). White crystals, mp $267{ }^{\circ} \mathrm{C}$ (lit. ${ }^{9} \mathrm{mp} \mathrm{260-264}{ }^{\circ} \mathrm{C}$ ). 
CI-MS m/z (rel. Int.): $579\left(6,[\mathrm{M}+1]^{+}\right), 489$ (2), 433 (4), 417 (16), 416 (8), 350 (2), 311 (6), 309 (18), 299 (30), 271 (100), 270 (25) 192 (8), 165 (78), 147 (40), 121 (18), 99 (5). ). HRCI-MS $m / z 579.151\left(\mathrm{M}^{+}+1\right)$, calcd for $\mathrm{C}_{30} \mathrm{H}_{26} \mathrm{O}_{12}$, 579.150. ${ }^{1} \mathrm{H}-\mathrm{NMR}$ of sugar protons (ppm, DMSO- $\left.d_{6}\right) \delta 3.30$ (1H, m, H-3"), 3.32 (1H, m, H-4"), 3.36 (1H, m, H-2"), 3.83 (1H, dd, J 7.8, 9.4 Hz, H-5"), 4.17 (1H, dd, J 4.8, $10.3 \mathrm{~Hz}$, H-6"b), 4.45 (1H, d, J 10.3 Hz, H-6"a), 5.16 (1H, d, J 8.0 $\mathrm{Hz}, \mathrm{H}-1$ ") ${ }^{13} \mathrm{C}-\mathrm{NMR}$ of sugar carbons (ppm, DMSO- $\left.d_{6}\right) \delta$ 63.4 (C-6"), 70.0 (C-4"), 72.9 (C-2"), 73.8 (C-5"), 76.2 (C3"), 99.5 (C-1").

6-Hydroxy-2-benzoxazolinone (2). Yellowish white crystals, mp $260{ }^{\circ} \mathrm{C}$, UV $\lambda_{\text {max }} / \mathrm{nm}(\mathrm{MeOH}): 340,305,302$, 268. EI-MS $m / z$ (rel. Int.) $152\left(6,[\mathrm{M}+1]^{+}\right), 151\left(25, \mathrm{M}^{+}\right)$, 149 (38), 142 (28), 130 (5), 122 (3, [M-(HCO)]), 117 (9), 107(5) 105 (21), 95 (21, [M+ -2CO]), 91 (14), 84 (22), 77 (14), 66 (30), 55 (38). HREI-MS m/z $151.027\left(\mathrm{M}^{+}\right)$; Calc. for $\mathrm{C}_{7} \mathrm{H}_{5} \mathrm{O}_{3} \mathrm{~N}, 151.026 .{ }^{1} \mathrm{H}$ - and ${ }^{13} \mathrm{C}-\mathrm{NMR}$ (Table 1 ).

4-Hydroxyacanthamine (3,4-dihydroxy-1,4benzoxazine-2-one) (3). Yellow needles, mp $135^{\circ} \mathrm{C}$. IR (KBr): $v_{\text {max }} / \mathrm{cm}^{-1}: 3325(\mathrm{OH}), 3050,2823,1670(\mathrm{CO}), 1550$, 1345. UV $\lambda_{\text {max }} / \mathrm{nm}(\mathrm{MeOH}): 290,279,253$. EI-MS $m / z$ (rel. Int.): $182\left(46,[\mathrm{M}+1]^{+}\right), 181\left(14, \mathrm{M}^{+}\right), 165$ (12), 164 (100, [M+-OH]), 136 (25), 108 (10). HRCI-MS m/z $181.144\left(\mathrm{M}^{+}\right)$; Cald. for $\mathrm{C}_{8} \mathrm{H}_{7} \mathrm{O}_{4} \mathrm{~N}, 181.145 .{ }^{1} \mathrm{H}$-and ${ }^{13} \mathrm{C}-\mathrm{NMR}$ (Table 1).

Alkaline hydrolysis of $\mathbf{3}$. A sample $(5 \mathrm{mg})$ of $\mathbf{3}$ was dissolved in $\mathrm{MeOH} / 3 \mathrm{~N} \mathrm{NaOH}(1: 1)$ and heated for fifteen minutes on water bath. The resulting solution was first extracted with EtOAc, acidified with dil. $\mathrm{HCl}$ and extracted with EtOAc. The EtOAc fraction, after acidification, showed a TLC spot with same $\mathrm{R}_{f}$ value of material 3 .

Potassium hydroxide fusion test of $\mathbf{3}$. A mixture of $\mathbf{3}$ $(3 \mathrm{mg}$ ) and $\mathrm{KOH}(15 \mathrm{mg}$ ) was fused in an oil bath for $30 \mathrm{~min}$. The reaction mixture was then allowed to cool, diluted with water and filtered. The filtrate was neutralized with dil. $\mathrm{HCl}$ and extracted with EtOAc. TLC revealed that the EtOAc extract resulting from the $\mathrm{KOH}$ fusion test was devoid of an ortho-aminophenol spot.

Acetylation of 3 . A sample $(4.0 \mathrm{mg})$ of $\mathbf{3}$ in pyridine $(2.0 \mathrm{~mL})$ was treated with $\mathrm{Ac}_{2} \mathrm{O}(0.2 \mathrm{~mL})$ for $24 \mathrm{~h}$ at room temperature. Evaporation of the mixture under a stream of nitrogen yielded chromatographically homogeneous 3a (4.0 mg). CI-MS m/z (rel. Int.): 266 (4, [M+1] $\left.]^{+}\right), 265$ (10, $\mathrm{M}^{+}$), 223 (16), 206 (100) 164 (169), 136 (20), 79 (5).

Apigenin 7-O- $\beta$-D-(6"-trans-p-coumaroyl) $3^{\prime \prime}-O$ acetylglucopyranoside (4). Pale yellow crystals, $\operatorname{mp} 223^{\circ} \mathrm{C}$. IR (KBr): $v_{\max } / \mathrm{cm}^{-1}: 3395(\mathrm{OH}), 3050,2820,1670(\mathrm{CO})$, 1560, 1320. UV $\lambda_{\text {max }} / \mathrm{nm}(\mathrm{MeOH}): 316,268,(\mathrm{NaOMe}) 368$, $300,272,\left(\mathrm{AlCl}_{3}\right), 375,325,319,298,276,\left(\mathrm{AlCl}_{3} / \mathrm{HCl}\right)$ 375, 325, 318, 298, 276, (NaOAc) 382, 318, 268. CI-MS

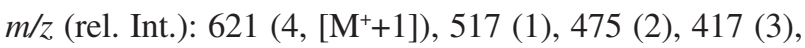

414 (3), 351 (51), 313 (7), 299 (15), 271 (52), 267 (6), 187 (13), 165 (35), 121 (100), 99 (18), 61 (84), HREIMS m/z $621.161\left(\mathrm{M}^{+}+1\right)$; Calç. for $\mathrm{C}_{32} \mathrm{H}_{28} \mathrm{O}_{13}, 621.160$. ${ }^{1} \mathrm{H}-\mathrm{NMR}$ (ppm, DMSO- $\left.d_{6}\right): \delta 2.07\left(3 \mathrm{H}, \mathrm{s}, \mathrm{COCH}_{3}\right), 3.48(1 \mathrm{H}, \mathrm{m}$, H-2"), 3.98 (2H, m, H-4", 5"), 4.20 (1H, dd, J 5.3, $11.7 \mathrm{~Hz}$, H-6”b), 4.43 (1H, H-6"a), 4.97 (1H, t, J9.6 Hz, H-3”), 5.30 (1H, d, J 7.8 Hz, H-1"), 6.35 (1H, d, J 16 Hz, H- $\alpha), 6.50$ (1H, d, J 1.9 Hz, H-6), 6.66 (2H, d, J 8.5 Hz, H-3"', 5"'), 6.84 (1H, d, J 1.9 Hz, H-8), 6.85 (1H, s, H-3), 6.92 (2H, d, J 8.9 Hz, H-3', 5'), 7.39 (2H, d, J 8.5 Hz, H-2'”, 6"' ), 7.49 (1H, $\mathrm{d}, J 16 \mathrm{~Hz}, \mathrm{H}-\beta), 7.94(2 \mathrm{H}, \mathrm{d}, J 8.9 \mathrm{~Hz}, \mathrm{H}-2$ ', 6 ' $) .{ }^{13} \mathrm{C}-\mathrm{NMR}$ (ppm, DMSO- $d_{6}$ ): $\delta 21.1\left(\mathrm{COCH}_{3}\right), 63.3$ (C-6"), 68.3 (C-4”), 71.3 (C-2”), 73.9 (C-5”), 77.4 (C-3”), 95.1 (C-8), 99.8 (C-1”, C-6), 103.4 (C-3), 105.9 (C-10), 114.0 (C- $\alpha$ ), 115.9 (C-3"', 5"'), 116.2 (C-3', 5'), 121.4 (C-1'), 125.4 (C-1'”), 128.8 (C-6'), 130.3 (C-2"', 6"'), 145.4 (C- $\beta$ ), 157.3 (C-9), 160.1 (C-4'), 161.4 (C-4"'), 161.7 (C-5), 162.8 (C-7), 164.7 (C-2), $166.8(\mathrm{C}=\mathrm{O}), 170.2\left(\underline{\mathrm{COCH}}_{3}\right), 182.3(\mathrm{C}-4)$.

Acanthaminoside (1,4-benzoxazine-2-one-3-Oglucoside) (5). Colourless needles, mp $213-214{ }^{\circ} \mathrm{C}$. IR (KBr) $v_{\max } / \mathrm{cm}^{-1}: 3475(\mathrm{OH}), 3125,2960,1700(\mathrm{CO}), 1600,1375$. UV $\lambda_{\max } / \mathrm{nm}(\mathrm{MeOH}): 283,275,250$. CI-MS m/z (rel. Int.): $328\left(14,[\mathrm{M}+1]^{+}\right), 327\left(14, \mathrm{M}^{+}\right), 166(100), 165$ (15.5), 164 (16, aglycone), 163 (13, glucosyl), 148 (100); 145 (30), 136 (18). HRCI-MS $m / z 327.095\left(\mathrm{M}^{+}\right)$, calcd for $\mathrm{C}_{14} \mathrm{H}_{17} \mathrm{O}_{8} \mathrm{~N}$, 327.095. ${ }^{1} \mathrm{H}$-and ${ }^{13} \mathrm{C}-\mathrm{NMR}$ (Table 1 ).

Acid hydrolysis of 5. A sample (6 mg) of 5 was dissolved in methanol $(10 \mathrm{~mL}) / 2 \mathrm{~N} \mathrm{HCl}(1 \mathrm{~mL})$ and heated under reflux for 1 hour. After cooling, the aqueous solution was extracted with EtOAc $(3 \times 5 \mathrm{~mL})$ and neutralized with $5 \%$ $\mathrm{Na}_{2} \mathrm{CO}_{3}$. TLC identified the sugar in the aqueous layer as glucose using $\mathrm{CHCl}_{3} / \mathrm{MeOH}$ (6:4) as developing system and thymol/ $\mathrm{H}_{2} \mathrm{SO}_{4}$ as spray reagent.

\section{Antimicrobial testing}

The MIC were determined for compounds $\mathbf{1}$ and 3-5 using a procedure described elsewhere. ${ }^{17}$ Twelve microorganisms: Bacillis subtilis, Micrococcus luteus, Sarcina lutea, Staphylococcus aureus, Bordetella bronchiseptica, Eschirichia coli, Klebsiella pneumoniae, Proteus mirabilis, Pseudomonas aeruginosa, Salmonella typhi, Serratia marcescens and Shigella sonnie were used in the study. The antibiotics ampicillin, ciprofloxacin, erythromycin and gentamicin were used as controls.

\section{Acknowledgments}

The authors are very grateful to Dr. Yousry Gohar for the antimicrobial testing and the Analytical Services Unit at Virginia Tech for spectral analyses. 


\section{References}

1. Airy Shaw, H.K.; Willis, J.C.; A Dictionary of the Flowering Plants and Ferns, $8^{\text {th }}$ ed., Cambridge University Press: Cambridge, 1973.

2. Reunaud, J.; Couble, A.; Rayanaud, J.; Pharmazie 1988, 43, 378.

3. D'Souza, L.; Wahidulla, S.; Mishra, P.D.; Ind. J. Chem. Sect. B: Org. Chem. Incl. Med. Chem. 1997, 36, 1079.

4. Anam, E.M.; Ind. J. Chem. Sect. B: Org. Chem. Incl. Med. Chem. 1997, 36, 109.

5. Kokpol, U.; Chittawong, V.; J. Nat. Prod. 1986, 49, 355.

6. Sam, J.; Valantine, J.L.; J. Pharm. Sci. 1969, 58, 1043.

7. Sam, J.; Plampin, J.N.; J. Pharm. Sci. 1964, 53, 538.

8. Kapil, A.; Sharma, S.; Wahidulla, S.; Planta Med. 1994, 60, 187.

9. Itokawa, H.; Suto, K.; Takeya, K.; Chem. Pharm. Bull. 1981, 29, 254.
10. Singh, K.N.; Pandey, V.B.; Banerjee, S.; Bohlmann. F.; Keinan, E.; Chem. Ind. (London, U. K.) 1986, 20, 713.

11. Markham, K.R.; Temai, B.; Stanley, R.; Geigen, H.; Mabry, T.J.; Tetrahedron 1978, 34, 1389.

12. Thomson, M.L.; DeJongh, D.C.; Can. J. Chem. 1973, 51, 13313.

13. Sissman, E.E.; LaPidus, J.B.; Beck, S.D.; J. Am. Chem. Soc. 1957, 79, 4697.

14. Fieser, L.F.; Williamson, K.L.; Organic Experiments, $4^{\text {th }}$ ed., D.C. Health and Company, Washington DC, 1979.

15. Chatterjee, A.; Basa, S.C.; Chem. Ind. (London, U. K.) 1969 , $15,328$.

16. Abdel-Kader, M.S.; Wisse, J.; Evans, R.; Werff, H.; Kingston, D.G.L.; J. Nat. Prod. 1997, 60, 1294.

17. Lorian, V.; Antibiotics in Laboratory Medicine, William's and Wilkin's: London, 1980.

Received: March 21, 2003

Published on the web: March 24, 2004 